\title{
Member News
}

\author{
Tang Prize Winner
}

The 2016 Tang Prize in Sinology was awarded to William Theodore de Bary for his tremendous academic and educational achievements. Born in 1919, Professor de Bary finished his doctoral degree in 1953 at Columbia University. He remains at his alma mater for the following decades and there he has established one of the

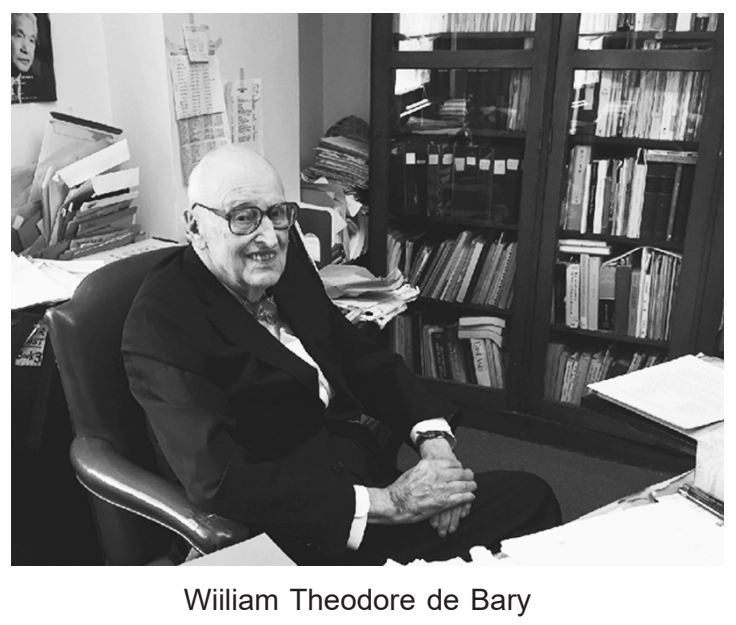
leading centers of Chinese studies in the West. The enterprise continues even after his retirement in 1990. Professor de Bary specializes in Chinese intellectual history, particularly Confucianism, and he has written and edited over 30 books, many of which have made groundbreaking contributions to Confucian studies. He chaired the Department of East Asian Languages and Culture between 1960 and 1966 and served as Executive Vice President of Academic Affairs and Provost from 1971 to 1978. He was also President of the Association of Asian Studies from 1969 to 1970. Even now in his nineties, he continues to publish works that address key questions of humanity, including his 2013 publication The Great Civilized Conversation: Education for a World Community. ${ }^{1}$

Professor de Bary's exploration of Confucianism began with his study of Huang Zongxi's (黃宗羲; 1610-1695) Waiting for the Dawn (明夷待訪錄). He strove to understand China's ideals, traditions, as well as internal problems faced throughout history, without the shackles of Western values and theories. With this insight, Professor de Bary went on to pioneer the field of Neo-Confucian studies with his 1953 article, "A Reappraisal of

1 Wm. Theodore de Bary, The Great Civilized Conversation: Education for a World Community (New York: Columbia UP, 2013). 
Neo-Confucianism." $2 \mathrm{He}$ does not hail traditional Confucian thought as perfect, but he endeavors to bring into light the Confucian idea of daotong (道統) or what he phrases as "the reconstitution of the Way."

Over the past half a century, Professor de Bary's research focuses on two major themes. The first is the discussion of the development of the Cheng-Zhu school of Neo-Confucianism from a historical perspective, which crystallized into two representative works: Neo-Confucian Orthodoxy and the Learning of the Mind-and-Heart and Message of the Mind in Neo-Confucianism. ${ }^{3}$ The second theme being his emphasis on the value of the individual and freedom in the Confucian tradition, a topic he explores in The Liberal Tradition in China. ${ }^{4}$ Professor de Bary stresses that Neo-Confucian teachings in late imperial China, especially during the Ming Dynasty, contain values that he terms "liberal tendencies." Throughout history, these values were upheld by Confucian scholar-officials, also known as junzi (君子; gentlemen), who would raise "prophetic voices" against the abuse of political power. In Learning for One's Self: Essays on the Individual in Neo-Confucian Thought, Professor de Bary tries to find common ground between the Confucian cultivation of the self and Western individualism. ${ }^{5}$

Despite his respect for Confucianism, Professor de Bary understands that both the "liberal tendencies" and "prophetic voices" were never translated into legal institutions to protect civil rights. In The Trouble with Confucianism, he argues that the Confucian ideal of cultivating sage kings is difficult to realize and must rely on junzi to mediate between the ruler and the people. While junzi were regarded as the spokesmen of the "mandate of heaven," unlike Western prophets, they were not ordained as God's messengers and lacked a power base such as the Church. Moreover, in the Confucian tradition, junzi mainly conveyed messages to the ruler rather than the people, which greatly limited their social impact. ${ }^{6}$ In his translation of Huang Zongxi's Waiting for the Dawn published in 1993, Professor de Bary provides a lengthy introduction, arguing that the elements of democracy found in Huang's work do not entirely fit in with Western democracy.

2 This article is included in Arthur Wright ed., Studies in Chinese Thought (Chicago: U of Chicago P, 1953).

3 Wm. Theodore de Bary, Neo-Confucian Orthodoxy and the Learning of the Mindand-Heart (New York: Columbia UP, 1981); Message of the Mind in Neo-Confucianism (New York: Columbia UP, 1989).

4 Wm. Theodore de Bary, The Liberal Tradition in China (Hong Kong: Chinese UP, 1983).

5 Wm. Theodore de Bary, Learning for One's Self: Essays on the Individual in Neo-Confucian Thought (New York: Columbia UP, 1991).

6 Wm. Theodore de Bary, The Trouble with Confucianism (Cambridge, Mass.: Harvard UP, 1991). 
Nevertheless, Huang's idea is of particular significance as he proposed a certain kind of rule of law, departing from traditional Confucian philosophy of politics. ${ }^{7}$

In recent years, Professor de Bary has shifted his focus to the comparison and complementariness between Western and Eastern civilizations. In 2004, he published Nobility and Civility: Asian Ideals of Leadership and the Common Good, in which he propounds a multicultural outlook and encourages cross-cultural dialogue as the best way to demonstrate the values of human rights and civil society and to resolve critical issues facing the contemporary world. ${ }^{8}$ Professor de Bary believes that the Confucian teachings of “subduing one's self and returning to propriety" (克已復禮) and “one principle with a myriad of manifestations" (理一分殊) are still applicable today. An earlier publication, in 1988, that heralded this vein of research is East Asian Civilizations: A Dialogue in Five Stages, in which Professor de Bary analyzes the development of East Asian civilizations, emphasizing exchanges between the different countries of this region, meanwhile making suggestions about dialogue between East and West. For him, to save a chaotic world, there is no way better than dialogue and exchange, whose promotion has long been the purpose of his scholarship.

Besides the dazzling scholarly achievements, Professor de Bary is also a great translator and editor. For decades, people in the field of East Asian studies, teachers and students alike, have all benefited from his Sources of Chinese Tradition, in which he translates and annotates a vast number of Chinese texts, including social, political, cultural, and intellectual sources. ${ }^{9}$ The work first came out in 1960 and has been continuously revised and enlarged. Professor de Bary also presides over a project of translating Eastern classics at Columbia University, which has seen more than 150 works translated and thus provided a solid foundation for Asian studies in the West. In addition, he has been holding seminars regularly and inviting scholars from around the world to discuss and publish their findings of Neo-Confucianism.

Overall, Professor de Bary has fostered a global conversation based on the common values and experiences shared by both East and West. To cite

7 Wm. Theodore de Bary, Waiting for the Dawn: A Plan for the Prince (New York: Columbia UP, 1993).

8 Wm. Theodore de Bary, Nobility and Civility: Asian Ideals of Leadership and the Common Good (Cambridge, Mass.: Harvard UP, 2004).

9 Wm. Theodore de Bary, Irene Bloom, eds., Sources of Chinese Tradition, Volume One (New York: Columbia UP, 1999). Also included in this series are Sources of Indian Tradition (2 volumes), Sources of Japanese Tradition (2 volumes), Sources of Korean Tradition (2 volumes), Sources of Vietnamese Tradition (1 volume), Sources of Tibetan Tradition (1 volume), etc. 
Dr. Rachel E. Chung's address at the 2016 Tang Prize awarding ceremony, he is not only a "bridge builder" but a "bridge" himself between Confucian traditions and the modern world. He exemplifies the spirit of "interculturation." 